\title{
Differentiation of fen bedrock in the Ełk Lakeland (NE Poland) in relation to late Pleistocene terrain morphogenesis
}

\begin{abstract}
The Ełk Lakeland (NE Poland) with the area of 263100 ha was formed during Vistulian glaciation. More than $66 \%$ of this region was shaped during the Leszno phase, $15 \%$ during the Poznan phase, and 19\% during the Pomeranian phase. There are 1854 fens which cover the area of $7.3 \%$ of the Ełk Lakeland mesoregion. Fens have an area of 10.3 ha on average. About $82.5 \%$ of the studied fens is located on gyttja deposits, which suggests post-lacustrine origin of the wetlands. Primary the lakes had covered $11 \%$ of the Ełk Lakeland, and $6.3 \%$ was transformed into fens. Most of them $(60 \%)$ was formed on organic gyttja, $16 \%$ on calcareous gyttja, and $6 \%$ on clay gyttja. About $17.5 \%$ of fens was formed as a result of paludification. The types of bedrock underlying peats differ depending on the phases of glaciation.
\end{abstract}

Key words: fens, gyttja, disappearance of lakes, the Ełk Lakeland

\section{INTRODUCTION}

The development of fens in young glacial areas depends on geomorphological conditions (particularly on the number and character of the original lakes occurring in negative landforms) and on the development of a river network. The land-forming intensity of lakes in the Masurian Lakeland (northern Poland) differed both in mesoregions, and in morphogenetic zones formed by the glacier of the Vistulian (Weichselian) glaciation. To date, half of the lakes of the Masurian Lakeland have been transformed into peatlands (Piaścik and Lemkowska 2004), with the zonation of this process being clearly depicted. The zonation is related to the latitudinal belts originated during the retreat of the Vistulian glaciation towards the north in the late Pleistocene (Marks 2005). These belts formed during the Leszno (Brandenburg), the Poznań (Frankfurt), and the Pomeranian phase (arranged here from the oldest to the youngest one). In the Masurian Lakeland, over $65 \%$ of the former lakes in the area formed in the Leszno phase were later transformed into peatlands, $30 \%$ - in the area formed in the Poznań phase, and 50\% - in the area formed in the Pomeranian phase (Lemkowska and Piaścik 2006). In the Ełk Lakeland, the original lakes covered about $11 \%$ of the area. The disappearance of lakes was assessed to be about $58 \%$, of which $56.5 \%$ were transformed into fens (Piaścik and Lemkowska 2004). The land formation in the area of former lakes, depending to a large extent on their size and depth, has determined the quantitative and qualitative differentiation of peatlands. The peat cover of particular morphogenetic zones of the Masurian Lakeland is at the level of $8.1 \%$ for the Leszno phase (L), $5.6 \%$ for the Poznan phase (POZ) and 7.0\% for the Pomeranian phase (POM) (Lemkowska and Piaścik 2006). The mean area is 20 ha for peatlands of the Leszno phase, 13 ha for peatlands of the Poznan phase, and 10 ha for peatlands of the Pomeranian phase. About $80 \%$ of peatlands located in the area of the Leszno phase (L) and $90 \%$ in the areas of younger phases (POZ, POM) are of post-lake origin (Lemkowska and Piaścik 2006). In this paper an attempt was made to examine the spatial differentiation of the fen bedrocks in the Ełk Lakeland (one of the mesoregions in the Masurian Lakeland, NE Poland) considering the morphogenesis of the area.

\section{MATERIALS AND METHODS}

The study was performed based on: geological documentation of the peatlands, database of peatlands of the NE region of Poland, and a map of distribution of peatlands of Poland prepared by the Institute for Land Reclamation and Grassland Farming (IMUZ) on a 1:100,000 scale. The extent of the phases of the Vistulian glaciation were determined according to Kondracki (1972). The areas formed in the particular phases were determined, and datasets of fens located 
within these areas were created. The peatlands were separated into lacustrine peatlands underlain with: mineral gyttja $(\mathrm{Gm})$, organic gyttja (Go) and calcareous gyttja (Gca), as well as peatlands formed as a result of paludification of mineral soils (M). The dominant genetic types of peat on the particular bedrock were determined. The data were compiled by size of peatlands and the thickness of the deposits was analysed. Spatial differentiation of peatlands was analysed based on the topographic maps on a 1:100,000 scale.

The Ełk Lakeland mesoregion, called Upland Masuria (in Polish: Mazury Garbate), occupies the eastern part of the Masurian Lakeland macroregion, and is distinguished by very diverse relief (Kondracki 1972). Richling (1985) distinguishes here 7 microregions with 5 different types of relief, bedrock, and percentage of the area covered by lakes and forests. The Ełk Lakeland is characterised by zonal hypsometric differentiation. Its northern part, formed during the Pomeranian and the Poznan phases of the Vistulian glaciation, is more elevated $(>200 \mathrm{~m}$ above sea level) and hilly, in comparison with its southern part formed in the Leszno phase. The landscape is dominated by loamy-sandy hills and hillocks surrounding lakes $(4.5 \%$ of the Lakeland area) using numerous concave landforms (Lossow 1996). The Ełk Lakeland is drained by tributaries of the Biebrza River, i.e. the Ełk and the Lega Rivers (Kondracki 1972). A large number of shallow and small lakes favoured the formation of wetlands which were created following prior shallowing by sediments (Churski 1988).

\section{RESULTS AND DISCUSSION}

The Ełk Lakeland mesoregion, with an area of 263100 ha, constitutes $20 \%$ of the Masurian Lakeland macroregion (Table). Around 66\% of the mesoregion's area was formed in the Leszno phase, $15 \%$ in the Poznań phase and $19 \%$ in the Pomeranian phase of the Vistulian glaciation. There are 1,854 fens in the Ełk Lakeland which cover $7.3 \%$ of region area (Table). Within the Leszno phase zone (L), 1,084 peatlands were found $(13,917 \mathrm{ha})$, in the zone of the Poznan phase - 387 (2,786 ha), and within the Pomeranian phase -383 (2,468 ha). In reference to the areas of the zones in which they are located, this accounts for about $8 \%$ of peat cover for the Leszno phase, $7 \%$ for the Poznan phase, and 5\% for the Pomeranian phase.

Peatlands with an area of less than 10 ha predominate in the Ełk Lakeland constituting $83 \%$ of total number of peatlands. The mean size of these wetlands
TABLE. Wetlands in the Ełk Lakeland

\begin{tabular}{lll}
\hline Specifications & $\begin{array}{l}\text { Mesoregion } \\
\text { PE }\end{array}$ & $\begin{array}{l}\text { Macroregion } \\
\text { PM }\end{array}$ \\
\hline Area (ha) & 263100 & 1318400 \\
Part of PM area (\%) & 20.0 & 100 \\
Number of fens & 1854 & 7346 \\
Area of fens (ha) & 19175 & 93741 \\
Part of postlake fens (\%) & 82.5 & 85.8 \\
Average size of fens (ha) & 10.3 & 12.8 \\
Area of gyttjalands (ha) & 358 & 5588 \\
\hline \% of region area: & & \\
Fens & 7.3 & 7.1 \\
Gyttjalands & 0.14 & 0.42 \\
Postlake fens & 6.02 & 6.09 \\
Current lakes area* & 4.50 & 6.41 \\
Primary lakes area & 10.66 & 12.92 \\
\hline Overgrown lakes (\%) & 56.5 & 47.1 \\
Lakes that disappeared (\%) & 57.8 & 51.4 \\
\hline
\end{tabular}

PE - the Ełk Lakeland mesoregion, PM - the Mazurian Lakeland macroregion, *According to Lossow (1996).

is only 10.3 ha (for the Leszno phase (L) it is 12.8 ha, for the Poznan phase (POZ) it is 7.2 ha, and for the Pomeranian phase (POM) it is 6.4 ha). Fens of all the zones of glaciation in the Ełk Lakeland are over 1.6 times smaller than in the analogous zones of the Masurian Lakeland (Lemkowska and Piaścik 2006).

The presence of gyttja (Go, Gm, Gca) in the bedrock of $83 \%$ of peatlands in the Ełk Lakeland indicates their lacustrine genesis. Taking into account the current area of the lakes, limnic peatlands, and gyttja lands, the author calculated that the percentage of the area originally covered by lakes was $11 \%$ of the Ełk Lakeland area. Over $60 \%$ of the fens were formed on organic gyttja, which ranks the Ełk Lakeland first compared to other mesoregions of the Masurian Lakeland (Piaścik and Lemkowska 2004). Organic gyttja predominates in the bedrock of all of the fens, regardless of their size (Fig. 1), and most often alderwood peats are deposited on this gyttja (Fig. 2). It should be noted that in the zone of the Leszno phase (L), the proportion of organic gyttja (61\%) is 3.5-fold higher, compared to the neighbouring Masurian Plain (17\%) formed entirely in the Leszno phase (L) (Piaścik and Lemkowska 2004), and it was 12-fold higher than in the zone of the Leszno phase (L) of the Great Masurian Lakes Region (5\%) (Lemkowska et al. 2013). Organic gyttja accumulated in highly trophic lakes, and its presence is characteristic for water bodies where there is no flow (Uggla 1969 and 1971, Stasiak 1971). In the bedrock of the studied fens in the Ełk Lakeland, organic gyttja reaches a thickness of $9 \mathrm{~m}$. Its location in a hilly landscape promoted migration and fertilisation of waters, increasing the trophicity of the wetlands. Organic gyttja also indicates later land-formation of lakes, 
FIGURE 1. Bedrock of fens in relation to size of objects (in ha) and terrain morphogenesis: PE - the whole Ełk Lakeland; L - area of the Leszno phase; POZ - area of the Poznań phase; POM - area of the Pomeranian phase; $\mathrm{M}$ - mineral bed, Go - organic gyttja; Gm - mineral gyttja; Gca - calcareous gyttja; SUM - summary of fens

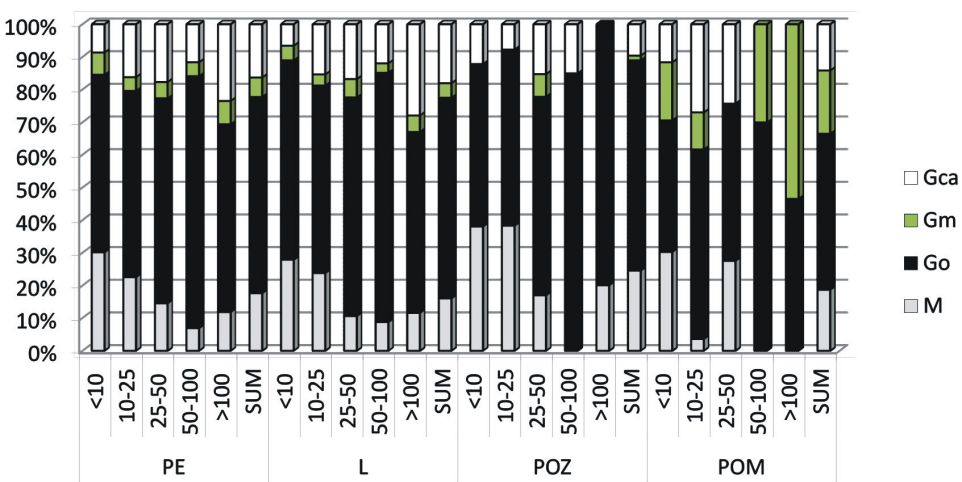

which is connected with climate cooling and with inhibition of calcium carbonate precipitation at the lake bottoms (Stasiak 1963), as a result of the inverse relation of coexistence of organic matter and calcium carbonate in lake sediments (Dean and Fouch 1983, Dean 1999, Punning et al. 2008).

Calcareous gyttja ( $\mathrm{Gca}$ ) is deposited in the bedrock of $16.4 \%$ of fens in the Ełk Lakeland (Fig. 1) which most often have a thickness of about $1.7 \mathrm{~m}$, up to a maximum of $7 \mathrm{~m}$. The frequency of occurrence of Gca, compared to the Olsztyn Lakeland, the Mragowo Lakeland, and the Masurian Plain, is 2-fold lower, and in comparison with the Great Masurian Lakes Region it is 3-fold lower (Piaścik and Lemkowska 2004), which indicates a much smaller amount of calcium carbonate washed out from post-glacial formations and deposited in former lakes. In the Ełk Lakeland, Gca most often occurs in the zone of the Leszno phase (L) (Fig. 1), and is characteristic for large fens, with tall-sedge and alder-wood peats (Fig. 2). The increased frequency of the occurrence of calcareous gyttja in the bedrock of fens of the Leszno phase (L) may be connected with the degree of washing out of calcium carbonate, which is more easily washed out from coarse-grained fluvio-glacial sediments than from glacial tills (Rzepecki 1985, Petelski and Sadurski 1987, Bukowska-Jania 2003). Taking into account that fluvioglacial formations contained about $15 \%$ calcium carbonate at the end of the last glaciation, (Bukowska-Jania and Pulina 1999), and comparing this with the current content of $\mathrm{CaCO}_{3}$ in soils (Kern 1985), one can state that up to the depth of $1.5 \mathrm{~m} \mathrm{CaCO}_{3}$ has been entirely washed out. This illustrates the level of chemical denudation and explains the localisation of the deposited calcareous gyttjas as a product of catchment erosion. It is thought that water flowing through sand-gravel formations with a carbonate content of $12 \%$ becomes saturated to degree comparable to waters migrating in calcareous rocks (Rzepecki 1985). The direction of water discharge from north towards south resulted in the possibility of an additional amount of carbonates being supplied to lakes of the Leszno phase from the zones of the younger phases, i.e. the Poznan and the Pomeranian phases (Bukowska-Jania 2003).

Since the solubility of $\mathrm{CaCO}_{3}$ decreases with increasing temperature, calcareous gyttja was accumulated in warm periods, when lowering the water level resulted in the shallowing of lakes and, as a consequence, in stronger heating and in the release of $\mathrm{CO}_{2}$ to the atmosphere, intensified by the rippling of water. According to Stasiak (1963), the maximum of this phenomenon in the Masurian Lakeland falls in the second half of the Atlantic period (8000-5000 BP). The formation of limnic calcareous sediments occurs as a result of biochemical and physical precipitation of $\mathrm{CaCO}_{3}$ in shallow basins. In deep water bodies, the $\mathrm{CO}_{2}$ content increases, which results in dissolution of $\mathrm{CaCO}_{3}$ (Więckowski 2009, Gierlowski-Kordesch 2010). Calcareous gyttja was accumulated in basins acting as sedimentation tanks for rivers (Więckowski 1993) and also in undrained depressions conserved by dead-ice (Goździk and Konecka-Betley 1992).

Mineral gyttja occurs only in $6.0 \%$ of fens in the Ełk Lakeland, which is similar to the Olsztyn Lakeland, but twice less frequently than the Mragowo Lakeland (Piaścik and Lemkowska 2004). The proportion of mineral gyttja is the greatest in the zone of the Pomeranian phase (POM), and in the zone of the Poznan phase (POZ) the gyttja occurs sporadically in the bedrock of smaller fens (Fig. 1).

About $17.5 \%$ of fens in the Ełk Lakeland are not genetically linked with lakes, and they were formed directly on the mineral bedrock (M) (Fig. 1). Fens with such bedrock are twice more numerous than in the Mragowo Lakeland and the Olsztyn Lakeland (Piaścik and Lemkowska 2004). This paludification index is the highest in the zone of the Poznan phase (POZ) (25\%), which would indicate specific hydrological conditions enabling the direct transformation of the land in mid-moraine depressions into peatlands. The favourable terrain configuration (Uggla et al. 


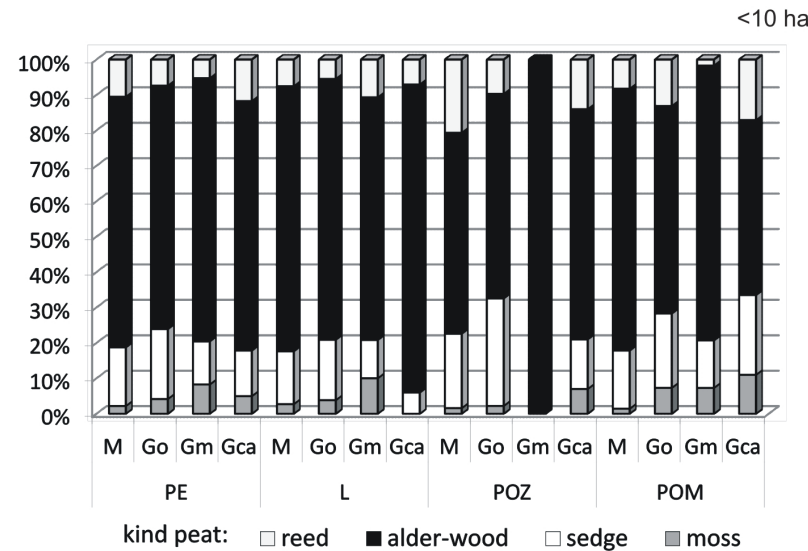

10-25 ha
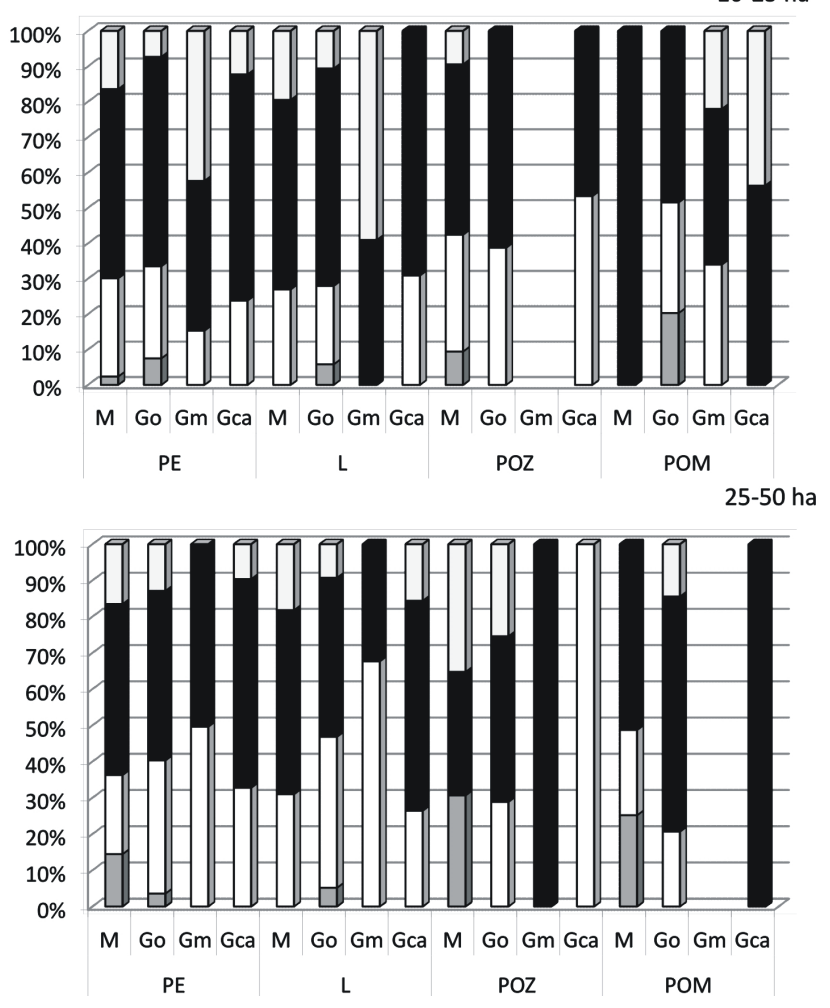

1967), the complex structure of the moraines and the soligenous and fluviogenous types of hydrological feeding have all contributed to this (Okruszko 1983). This is confirmed by the relatively small sizes of these fens, with which they could function when fed only with water flowing down from neighbouring hills (Stepa et al. 1995). The fertility of waters feeding wetlands is correlated with geomorphological factors. During the flow of water, it becomes enriched in nutrients, and their amount depends on the soil types the water is passing through (Żurek 1990). The effect of the catchment in this process was emphasised by Uggla (1964).

Peat deposits of the studied wetlands in the Ełk Lakeland are mostly classified $(68.5 \%)$ as deep deposits with thickness more than $130 \mathrm{~cm}$ (Fig. 3).
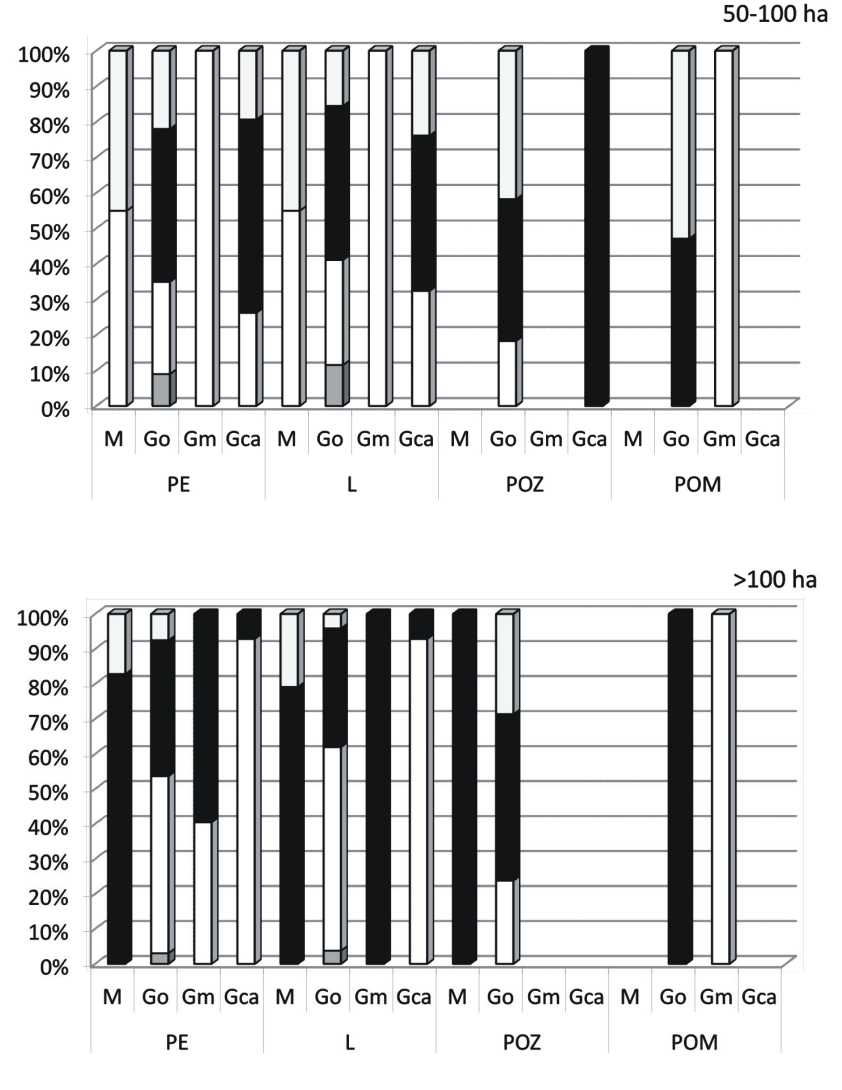

FIGURE 2. Kinds of peat in the Ełk Lakeland in relation to fen bedrock and terrain morphogenesis (separately for different sizes of fens from $<10$ to $>100 \mathrm{ha}$ ). Abbreviations were explained in Fig. 1

Their proportion is $13 \%$ greater in comparison with the mean for the whole Masurian Lakeland (Lemkowska and Piaścik 2006). In the zone of the Leszno phase (L) deep peat deposits constitute $63 \%$, in the Poznan phase (POZ) $88 \%$, and in the Pomeranian phase (POM) 77\%. The peat deposits in the Ełk Lakeland on average have a thickness of $1.6 \mathrm{~m}$ to a maximum of $6.2 \mathrm{~m}$. In the zone of the Leszno phase (L), with milder relief, deposits are noticeably shallower than in the younger phases (Fig. 3). There are twice as many shallow peatlands $(<80 \mathrm{~cm})$ than in the zones of the Poznan phase (POZ) and of the Pomeranian phase (POM). These peatlands are usually of small size, and alder-wood peats dominate in the deposit. The thickness of the deposits reflects the differentiation of concave forms and of hydrological conditions in 
FIGURE 3. Thickness of peat in fens for each phase of Vistulian glaciation (L, POZ, POM), for the whole Ełk Lakeland (PE), and for different fens sizes (from $<10$ to $>100$ ha). Abbreviations were explained in Fig. 1

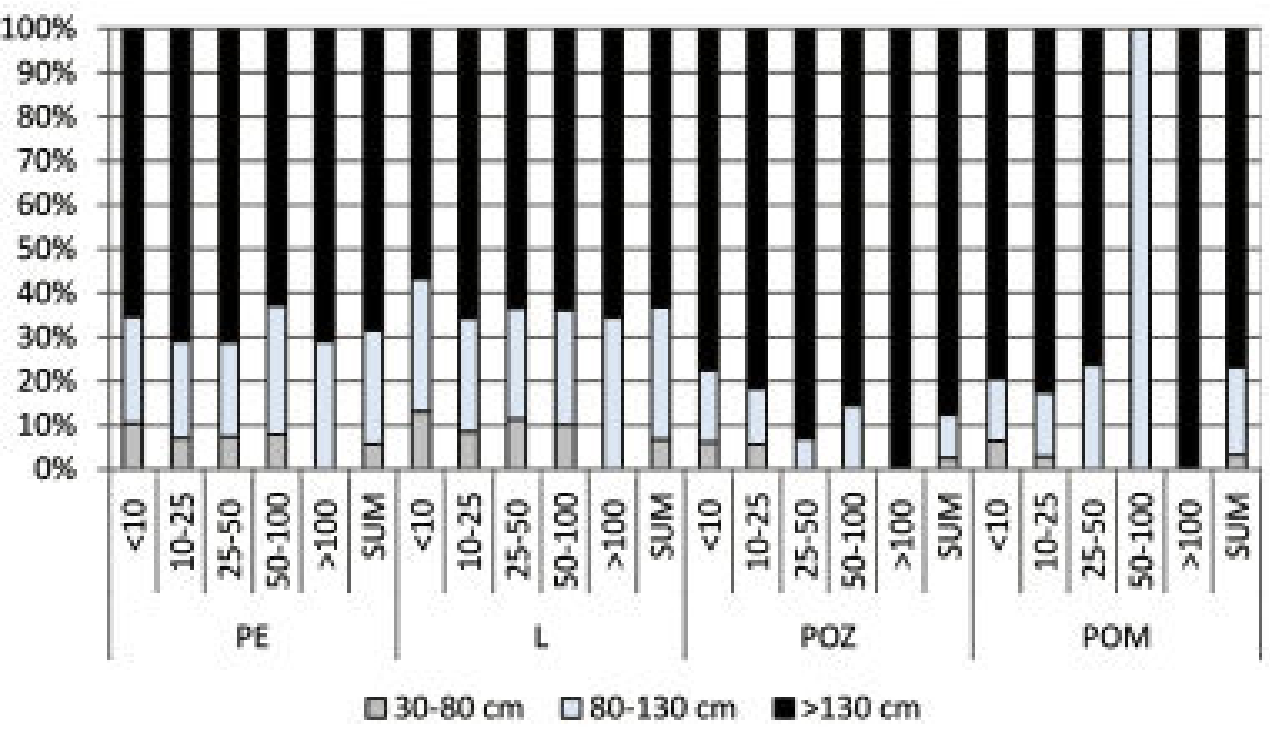

the areas formed during particular phases of the Vistulian glaciation. The dominance of organic gyttja in the bedrock of peatlands contributed to maintaining a high water level, ensuring favourable conditions for the accumulation of peat and for the formation of deposits of great thickness.

Studies completed to date have shown that wetlands are an integral part of the natural environment, they combine various landscapes and enrich them ecologically. Their formation is connected with the geological, geomorphological, and hydrological conditions of a particular area (Żurek 1969 and 1990, Dembek 2000, Lemkowska and Piaścik 2006). The distribution and specificity of these biotopes exhibit regional differentiation referring to the physical-geographical division and morphogenesis of the area. Interest in wetlands is growing due to the important role which they play in carbon turnover. The sparse knowledge of carbonate sediments and the need for more studies are also emphasised. Scientists are becoming increasingly aware that these areas are unrecognised reservoirs of knowledge concerning climate, geochemical, and hydrological processes (Alonso-Zarza and Wright 2010) and can help to forecast environmental changes.

FIGURE 4. Distribution of fens in the Ełk Lakeland

\section{CONCLUSIONS}

1. Two-thirds of the Ełk Lakeland area was formed in the Leszno phase of the Vistulian glaciation, and one-third was formed in the younger Poznań and Pomeranian phases.

2. The morphogenetic conditions of the Ełk Lakeland related to phases of the Vistulian glaciation influenced the spatial, quantitative, and qualitative differentiation of fens. Fen formation in the zones formed in particular phases of the Vistulian

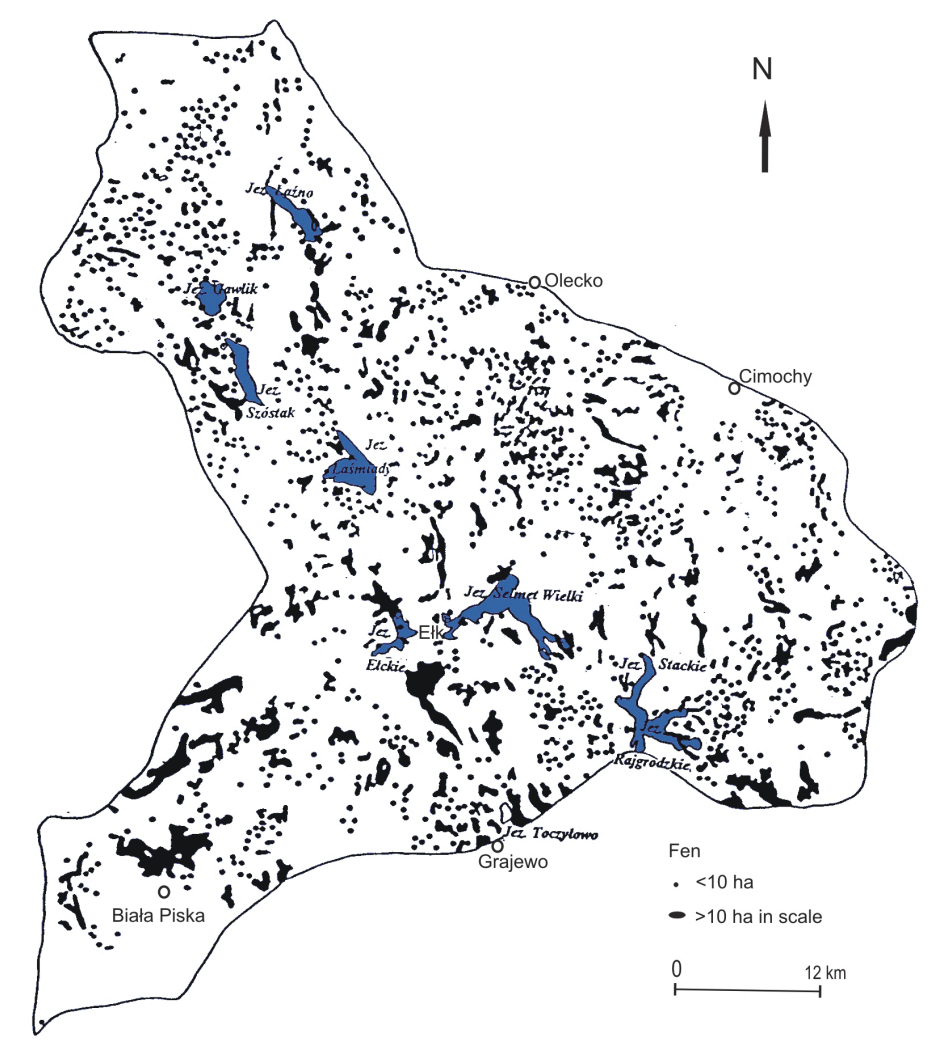


glaciation is connected with the number and size of the original lakes, and with the degree of their transformation into land. It decreases toward the north with increasing terrain elevation and increasing terrain relief.

3. Majority of the studied fens in the area of Ełk Lakeland was located on gyttja deposits, which suggests post-lacustrine origin of the wetlands. The proportion of organic gyttja in bedrock increases towards the south. Most of paludification peatlands were formed in the Poznan phase.

4. The smaller proportion of calcareous gyttja in the bedrock of fens of the Ełk Lakeland, compared to the neighbouring regions (the Great Masurian Lakes Region and the Masurian Plain) indicates post-glacial deposits were poorer in $\mathrm{CaCO}_{3}$ in the Ełk Lakeland. It also indicates a weaker degree of chemical denudation and less favourable conditions of calcium carbonate re-deposition.

\section{REFERENCES}

Alonso-Zarza A.M., Wright V.P., 2010. Palustrine Carbonates [In:] Carbonates in Continental Settings, Facies, Environments, and Processes. (Alonso-Zarza A.M., Tanner L.H., Eds.). Developments in Sedimentology 61: Elsevier Science Amsterdam, London: 103-131.

Bukowska-Jania E., 2003. The role of glacier systems in the migration of calcium carbonate in the natural environment. Wyd. Uniwer. Śląskiego, Katowice: 247 pp. (In Polish with English summary).

Bukowska-Jania E., Pulina M., 1999. Calcium carbonate in deposits of the last Scandinavian glaciation and contemporary chemical denudation in west Pomeranian - NW Poland, in the light of modern processes in Spitsbergen. Zeitschrift für Geomorphologie N.F. Suppl. Gebrüder Borntraeger, Berlin, Stuttgart 119: 21-36.

Churski Z., 1988. Selected issues of lakes and wetlands in Poland. [In:] Natural and anthropogenic changes lakes and wetlands in Poland (Churski Z., Ed.), Rozprawy UMK Toruń: 9-31 (In Polish).

Dean W.E., 1999. The carbon cycle and biogeochemical dynamics in lake sediments. Journal of Paleolimnology 21: 375-393.

Dean W.E., Fouch T.D., 1983. Lacustrine environment. [In:] Carbonate Depositional Environments (Scholle P.A., Bebout D.G., Moore C.H., Eds.), AAPG Memoir 33: 97-130.

Dembek W., 2000. Selected aspects of diversification of peatlands in the young and old glacial landscapes of eastern Poland. Habilitation. Wyd. IMUZ, 175 pp. (In Polish).

Goździk J., Konecka-Betley K., 1992. Late-Vistulian carbonateous formations in outflow-closed depressions of the Bełchatów brown coal strip mine. Part I. Genesis and stratigraphy. Part II. Chemical and mineral composition. Roczniki Gleboznawcze - Soil Science Annual 43(3-4): 103-124 (In Polish with English summary).

Gierlowski-Kordesch E.H., 2010. Lacustrine Carbonates. [In:] Carbonates in Continental Settings, Facies, Environments, and Processes. (Alonso-Zarza A.M., Tanner L.H., Eds.).
Developments in Sedimentology 61: Elsevier Science Amsterdam, London: 1-101.

Kern H., 1985. Reaction and calcium carbonate in soil profiles of agricultural land Polish. Wyd. IUNG R(201). Puławy: 97 pp. (In Polish).

Kondracki J., 1972. North-Eastern Poland. (Polska północnowschodnia). PWN, Warszawa: 272 pp. (In Polish).

Lemkowska B., Piaścik H., 2006. Differentiation of fens in landscapes of the Mazurian Lakeland. Polish Journal of Environmental Studies 15(5D): 43-46.

Lemkowska B., Orzechowski M., Smólczyński S., 2013. Differentiation of fens base in the Great Mazurian Lakes Region according to terrain morphogenesis. [In:] Environment soil formation and soil of river valleys (Jonczak J., Florek W., Eds.). Bogucki Wydawnictwo, Poznań: 95-102 (In Polish with English abstract).

Lossow K., 1996. Significance of lakes in postglacial landscape of the Masurian Lakeland. Zeszyty Problemowe Postępów Nauk Rolniczych 431: 47-59 (In Polish with English summary).

Marks L., 2005. Pleistocene glacial limits in the territory of Poland. Przegląd Geologiczny 53(10/2): 988-993.

Okruszko H., 1983. Differentiation of hydrologic conditions of wetlands under their reclamation point of view. Wiadomości IMUZ, 15(1): 13-31 (In Polish with English summary).

Petelski K., Sadurski A., 1987. Lake chalk indicator Holocene exchange of groundwater. Przegląd Geologiczny 3: 143-147 (In Polish with English summary).

Piaścik H., Lemkowska B., 2004. Genesis of fens in the Masurian Lakeland. (Genese der niedermoore in der Masurischen Seeplatte). Telma 34: 31-37 (In German with English abstract).

Richling A., 1985. Typology of physico-geographical microregions within Suwałki voivodship. Przegląd Geograficzny 57 (1-2): 123-138 (In Polish with English summary).

Prace Geograficzne. Wydawnictwo Geologiczne, Warszawa, 42: 94 pp. (In Polish with English summary).

Punning J.M., Kapanen G., Hang T., Davydova N., Kangur M., 2008. Changes in the water level of Lake Peipsi and their reflection in a sediment core. Hydrobiologia 599: 97-104.

Rzepecki P., 1985. Lacustrine calcareous deposits of Northern Poland between Łyna and Brda rivers. Geologia 11(3): 5-78 (In Polish with English summary).

Stasiak J., 1963. History of Kruklin lake as revealed by the deposits of its littoral zone.

Stasiak J., 1971. Genesis of sedimentation basins on outwash plains. Zeszyty Problemowe Postepów Nauk Rolniczych 107: 103-112 (In Polish with English summary).

Stepa T., Tomaszewska K., Wojtuń T., 1995. Oddziaływanie stoków morenowych na właściwości siedlisk strefy brzeżnej i środkowej małego torfowiska koło Wilkowa na Pojezierzu Mazurskim. Wiadomości IMUZ 34: 63-70 (In Polish with English summary).

Uggla H., 1964. The Influence of the drainage area on the formation and some properties of the lake sediments. Zeszyty Naukowe WSR Olsztyn 17 (355): 645-654 (In Polish with English summary).

Uggla H., 1969. Gyttja soils in the Masurian Lakeland. I. General characteristics of the gyttja soils and gyttja-muck soils. II. Physical, chemical and biological properties of gyttja soils and gyttja-muck soils. Zeszyty Naukowe WSR Olsztyn 25(3): 563-606 (In Polish). 
Uggla H., 1971. Characteristics of gyttja and gyttja soils of Mazurian Lakeland in light of hitherto investigations of the Chair of Pedology WSR in Olsztyn. Zeszyty Problemowe Postępów Nauk Rolniczych 107: 13-25 (In Polish with English summary).

Uggla H., Grabarczyk S., Mirowski Z., Nożyński A., Rytelewski J., Solarski H., 1967. The process of water erosion in the landscape of hills of North-Eastern Poland. Zeszyty Naukowe WSR Olsztyn 23(2): 225-243 (In Polish with English summary).

Więckowski K., 1993. The processes of sedimentation and the pace of accumulation of sediments in selected lakes. [In:] Changes in water relations in Poland as a result of natural processes and anthropogenic (Dynowska I., Ed.), Kraków: 88-97 (In Polish).
Więckowski K., 2009. Issues origins, age and evolution of lakes of all Polish regions in the light of their bottom sediments. Studia Limnologica et Telmatologica. Suplement 1: 29-72 (In Polish).

Żurek S., 1969. The peat deposits of Grajewo county, with geomorphological conditions as backgroun. 41(3): 469-483 (In Polish with English summary).

Żurek S., 1990. Relationship between peat formation process and natural environment elements in East Poland. Roczniki Nauk Rolniczych D-220: 174 pp. (In Polish).

\section{Zróżnicowanie podłoża torfowisk niskich Pojezierza Ełckiego na tle późnoplejstoceńskiej morfogenezy terenu}

Streszczenie: Pojezierze Ełckie o powierzchni 263100 ha zostało ukształtowane podczas zlodowacenia Wisły. Około 66\% terenu Pojezierza uformował lądolód w fazie leszczyńskiej, $15 \%$ - w fazie poznańskiej, a $19 \% \mathrm{w}$ fazie pomorskiej. Występują tu 1854 torfowiska niskie, które zajmują 7,3\% powierzchni mezoregionu. Średnia ich wielkość wynosi 10,3 ha. W podłożu większości torfowisk $(82,5 \%)$ dominuje gytia, co świadczy o ich pojeziernej genezie. Pierwotnie jeziora zajmowały $11 \%$ powierzchni mezoregionu, z czego 6,3\% przekształciła się w torfowiska niskie. Większość torfowisk niskich (60\%) rozwinęło się na gytii organicznej, ponad $16 \%$ na gytii wapiennej, a $6 \%$ na gytii ilastej. W wyniku paludyfikacji powstało $17,5 \%$ torfowisk niskich. Stwierdzono zróżnicowanie w utworach podtorfowych pomiędzy torfowiskami usytuowanymi w różnych strefach zlodowacenia.

Słowa kluczowe: torfowiska niskie, gytia, zanik jezior, Pojezierze Ełckie 